\title{
PENGARUH BAHAN PENGISI SILIKA DAN SERBUK TANDAN KOSONG SAWIT (STKS) TERMODIFIKASI TERHADAP KEKUATAN BENTUR DAN DAYA SERAP AIR KOMPOSIT HIBRID POLIESTER TIDAK JENUH
}

\author{
Halimatuddahliana, Johan Evander Sirait, Fermadi Sirait \\ Departemen Teknik Kimia, Fakultas Teknik, Universitas Sumatera Utara, \\ Jl.Almamater Kampus USU, Medan 20155, Indonesia \\ Email: Johan.Sirait92@gmail.com
}

\begin{abstract}
Abstrak
Penelitian ini bertujuan untuk mengetahui pengaruh penambahan serbuk tandan kosong sawit (STKS) dan silika ke dalam matriks resin poliester tidak jenuh (UPR) serta pengaruh modifikasi kimia STKS dengan menggunakan asam asetat $50 \%(\mathrm{v} / \mathrm{v})$. Pada penelitian ini, UPR dicampurkan dengan silika dan STKS dengan perbandingan berat (UPR : Silika : STKS) $80: 20$ $: 0,80: 15: 5,80: 10: 10,80: 5: 15,80: 0: 20$ dengan metode hand lay-up. Analisa yang dilakukan berupa uji bentur yang didukung oleh analisa scanning electron microscopy (SEM). Hasil menunjukkan bahwa kekuatan bentur komposit dengan modifikasi STKS pada rasio 80:5:15 lebih tinggi dibandingkan tanpa modifikasi yaitu sebesar $3622,5 \mathrm{~J} / \mathrm{m}^{2}$. Dalam hal ini modifikasi kimia telah menurunkan polaritas STKS sehingga tegangan permukaan (interfacial tension) antara pengisi dengan matriks menjadi rendah yang menghasilkan interaksi antar muka dan pelekatan antara matriks dan pengisi relatif menjadi lebih baik. Nilai kekuatan bentur tersebut didukung oleh hasil SEM. Dari daya serap air, modifikasi kimia menunjukkan daya serap yang lebih rendah dibandingkan dengan tanpa modifikasi yang mengindikasikan bahwa modifikasi telah menurunkan polaritas pengisi STKS.
\end{abstract}

Kata Kunci: resin poliester tidak jenuh, serbuk tandan kosong sawit, silika, uji bentur, hibrid, modifikasi.

\begin{abstract}
This research aims to determine the effect of palm oil empty fruit bunches (POEFB) powder and silica into the matrix of unsaturated polyester resin (UPR) and the influence of chemical modification OPEFB with using acetic acid 50\% (v/v). In this study, (UPR) was mixed with silica and OPEFB to weight ratio (UPR: Silica: OPEFB) 80:20:0, 80: 15:5, 80: 10: 10, 80: 5: 15, 80: 0: 20 by hand lay-up method. Analysis was done by impact test, and analysis of scanning electron microscopy (SEM). Results showed that impact strength at a ratio of 80: 5: 15 was higher than those without modification viz. $3622.5 \mathrm{~J} / \mathrm{m}^{2}$. In this case the chemical modification has lowered OPEFB polarity so that the interfacial tencion between the filler with a matrix became low resulting in good interfacial interaction and adhesion between matrix and fille. Impact strength values were supported by the results of SEM. From water adsorption test, composite with chemical modification showed low values as compared without modification indicating that modification has lowered the polarity of OPEFB.
\end{abstract}

Keywords: unsaturated polyesters resin, oil palm empty fruit bunches powder, silica, impact test hybrid, modified.

\section{Pendahuluan}

Komposit adalah suatu material yang terbentuk dari kombinasi dua atau lebih material dimana sifat dan karakteristik dari material pembentuknya berbeda-beda [12]. Komposit polimer komersil selama ini umumnya menggunakan bahan polimer termoset. Jenis yang umum digunakan adalah resin poliester, epoksi, dan urea-formaldehida. Di antara ketiga bahan termoset ini, resin poliester tidak jenuh (unsaturated polyester resin) merupakan bahan termoset yang paling banyak digunakan karena memiliki sifat penyusutan yang rendah, dapat dicetak pada suhu ruangan, viskositas yang rendah, ketahanan termal dan cuaca yang baik serta harganya yang relatif murah [11]. Salah satu jenis komposit yang berkembang saat ini adalah komposit hibrid, dimana komposit ini terdiri dari dua jenis atau lebih pengisi. Tujuan dari hibridisasi adalah untuk menghasilkan suatu material yang mengandung kelebihan dari penyusunnya [5].

Bahan pengisi matriks polimer yang banyak digunakan sebagai bahan untuk memperkuat komposit adalah serat alam. Serat alam yang digunakan mengandung lignoselulosa banyak terdapat pada limbah kelapa sawit, antara lain tandan kosong, batang, dan pelepah kelapa sawit [8]. Penambahan serbuk tandan kosong kelapa sawit pada prinsipnya adalah menyisipkan serat tersebut ke dalam rantai-rantai polimer yang mengakibatkan tereduksinya mobilitas rantai-rantai polimer [6]. Sementara itu, Silika yang banyak digunakan dalam industri-industri, dikarenakan sifat dan morfologinya yang unik, diantaranya: luas 
permukaan dan volume porinya yang besar, dan kemampuan untuk menyerap berbagai zat seperti air, oli dan bahan radioaktif, juga telah digunakan sebagai pengisi anorganik [7]. Penggunaan silika diharapkan mampu menaikkan kekuatan mekanik komposit, karena silika memiliki kemampuan menyerap air dan sebagai bahan pengeras [7].

Proses pencampuran matriks dengan pengisi umumnya cenderung tidak berlangsung secara homogen karena sifat kedua bahan yang mempunyai kepolaran berbeda. Salah satu upaya untuk menghasilkan komposit dengan sifat-sifat mekanik yang baik perlu dilakukan modifikasi terhadap bahan pengisi sehingga polaritasnya berkurang [1].

Modifikasi kimia pada pengisi didefenisikan sebagai interaksi antara beberapa bagian reaktif dari polimer dinding sel lignoselulosa dengan pelarut kimia tunggal baik dengan katalis ataupun tanpa katalis untuk membentuk ikatan kovalen antara keduanya. Secara umum, modifikasi kimia dapat mengurangi jumlah gugus - $\mathrm{OH}$ pada pengisi, mengurangi lignin, pektin, wax dan minyak pada permukaan dinding sel pengisi [1].

\section{Teori}

Komposit adalah suatu material yang terbentuk dari kombinasi dua atau lebih material dimana sifat dan karakteristik dari material pembentuknya berbeda-beda [12].

Klasifikasi komposit dapat dibentuk dari sifat dan strukturnya. Bahan komposit dapat diklasifikasikan kedalam beberapa jenis. Secara umum klasifikasi komposit terdiri dari [12]:

1. Klasifikasi menurut kombinasi material utama, seperti metal-organic atau metal anorganic.

2. Klasifikasi menurut karakteristik bulk-form, seperti sistem matrik atau laminasi.

3. Klasifikasi menurut distribusi unsur pokok, seperti continous dan discontinous.

4. Klasifikasi menurut fungsinya, seperti elektrikal atau struktural.

Sedangkan klasifikasi untuk komposit serat (fiber-matrik composites) dibedakan menjadi beberapa macam antara lain [12]:

1. Fiber composites (komposit serat) adalah gabungan serat dengan matrik.

2. Flake composites adalah gabungan serpih rata dengan matrik.

3. Particulate composites adalah gabungan partikel dengan matrik.

4. Filled composites adalah gabungan matrik continous skeletal dengan matrik yang kedua.

5. Laminar composites adalah gabungan lapisan atau unsur pokok lamina.

Secara umum bahan komposit terdiri dari dua macam, yaitu bahan komposit partikel (particulate composite) dan bahan komposit serat (fiber composite). Bahan komposit partikel terdiri dari partikel-partikel yang diikat oleh matrik. Bahan komposit serat terdiri dari serat-serat yang diikat oleh matrik yang saling berhubungan. Bahan komposit serat ini terdiri dari dua macam, yaitu serat panjang (continuos fiber) dan serat pendek (short fiber atau whisker). Penggunaan bahan komposit serat sangat efisien dalam menerima beban dan gaya [10].

Untuk memperoleh komposit yang kuat harus dapat memempatkan serat dengan benar. Berdasarkan penempatannya terdapat beberapa tipe serat pada komposit, yaitu [4] :

1. Continuous Fiber Composite

Tipe ini mempunyai susunan serat panjang dan lurus, membentuk lamina diantara matriknya. Jenis komposit ini paling sering digunakan. Tipe ini mempunyai kelemahan pada pemisahan antar lapisan. Hal ini dikarenakan kekuatan antar lapisan dipengaruhi oleh matriknya.

2. Woven Fiber Composite (bi-directional)

Komposit ini tidak mudah dipengaruhi pemisahan antar lapisan karena susunan seratnya juga mengikat antar lapisan. Akan tetapi susunan serat memanjangnya yang tidak begitu lurus mengakibatkan kekuatan dan kekakuan akan melemah.

\section{Discontinuous Fiber Composite}

Discontinuous Fiber Composite adalah tipe komposit dengan serat pendek.

4. Hybrid Fiber Composite

Hybrid fiber composite merupakan komposit gabungan antara tipe serat lurus dengan serat acak. Tipe ini digunakan supaya dapat menganti kekurangan sifat dari kedua tipe dan dapat menggabungkan kelebihannya.

\section{Metodologi Penelitan}

Alat

Alat yang digunakan dalam penelitian ini antara lain neraca elektrik, gelas ukur, beaker glass, kuas atau roller, ball mill, blender, dumble cutter, kaca, lilin mainan, alat uji bentur, Scanning Electron Microscopy (SEM).

\section{Bahan}

Bahan yang digunakan dalam penelitian ini adalah Poliester tidak jenuh (UPR), Katalis Methyl Ethyl Ketone Peroxide (MEKP), Serbuk tandan kosong sawit, Silika.

\section{Prosedur Penyediaan STKS}

Serat tandan kelapa sawit dicuci menggunakan air bersih, lalu dikeringkan dibawah terik matahari. Setelah kering STKS dipotongpotong dengan menggunakan gunting sampai kecil, dan digiling menggunakan ball mill, kemudian serat STKS diblender hingga berbentuk serbuk, setelah itu STKS diayak menggunakan ayakan berukuran 50 mesh. 
Prosedur Modifikasi Kimia STKS [3]

Pengisi STKS dengan ukuran 50 mesh dan berat yang telah ditetapkan dilarutkan ke dalam larutan asam asetat 50\% (v/v) dan diaduk selama 1 jam dengan pengaduk. Setelah 1 jam larutan dipisah dengan kertas saring agar terpisah larutan dan pengisi. Pengisi dicuci beberapa kali dengan air suling dan dikeringkan di dalam oven pada suhu $80^{\circ} \mathrm{C}$ selama 24 jam. Perbandingan pengisi dengan asam asetat adalah 1:20 (b/v).

Prosedur Penyediaan Komposit Poliester Tidak Jenuh Berpengisi Serbuk Tandan Kosong Sawit [9]

Resin poliester tidak jenuh dicampurkan dengan pengisi serbuk tandan kosong dan silika ke dalam Beaker glass dengan perbandingan berat (UPR : Silika : STKS) $80: 20: 0,80: 15: 5,80$ : $10: 10,80: 5: 15,80: 0: 20$, campuran diaduk perlahan selama 5 menit hingga merata, ditambahkan katalis MEKP sebanyak $1,5 \%$ berat dari berat matriks campuran diaduk selama 2 menit [9]. Alas cetakan kaca terlebih dahulu diberikan bahan pelicin seperti kit mobil agar resin tidak melekat pada cetakan, selanjutnya campuran bahan dituang ke dalam cetakan yang sudah disiapkan dari malam (lilin mainan) dan kaca yang telah dibentuk sesuai standar ASTM D 4812-11, diratakan permukaan campuran pada cetakan, ditunggu hingga kering, Komposit yang sudah kering dilepas dari cetakan kemudian bagian dihaluskan bagian-bagian permukaannya dengan alat kikir dan amplas, dilakukan pengujian terhadap komposit yaitu uji kekuatan bentur (impact strength) dan analisa scanning electron microscopy (SEM).

\section{Uji Kekuatan Bentur (Impact Strength)}

Pengujian impak bertujuan untuk mengukur berapa energi yang dapat diserap suatu material sampai material tersebut patah. Pengujian impak merupakan respon terhadap beban kejut atau beban tiba-tiba (beban impak) [2]. Pengujian Bentur dilakukan dengan mesin Gotech menurut standar ASTM D 4812-11.

\section{Analisa Scanning Electron Microscopy (SEM)}

Analisa SEM untuk melihat perubahan morfologi yang terjadi pada patahan komposit. Sampel yang dianalisa yaitu hasil uji bentur komposit UPR berpengisi silika dan STKS dengan dan tapa modifikasi.

\section{Hasil dan Pembahasan}

Pengaruh Komposisi Bahan Pengisi Terhadap Kekuatan Bentur (Impact Strength) Komposit Hibrid Poliester Tidak Jenuh

Gambar 1 menunjukkan pengaruh penambahan bahan pengisi dan pengaruh modifikasi kimia pada STKS terhadap kekuatan bentur (Impact Strength)

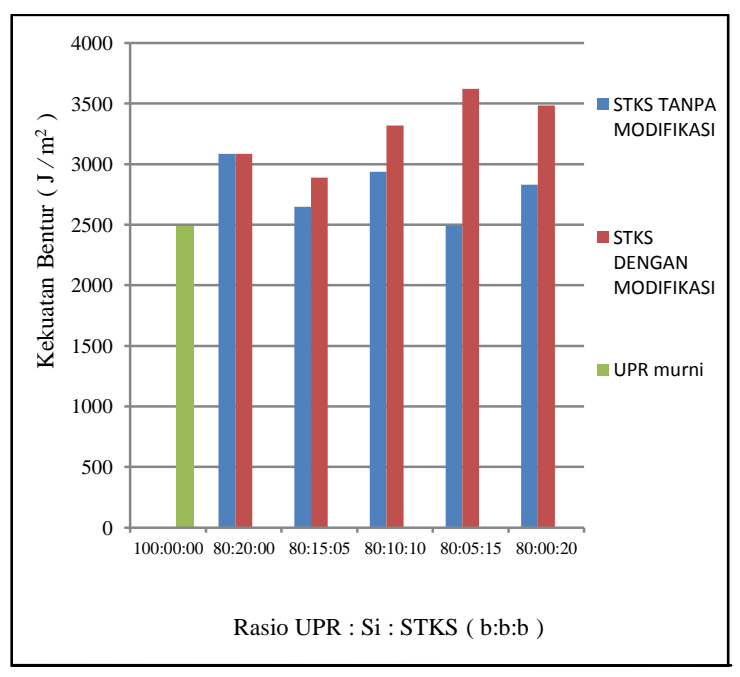

Gambar 1. Pengaruh Komposisi Bahan Pengisi dan Pengaruh Modifikasi Kimia Pada STKS Terhadap Kekuatan Bentur Komposit

Gambar 1 menunjukan pengaruh penambahan bahan pengisi dengan atau tanpa modifikasi kimia terhadap kekuatan bentur, dimana nilai kekuatan bentur komposit STKS modifikasi lebih tinggi dari nilai kekuatan bentur komposit STKS tanpa modifikasi. Dalam hal ini, modifikasi kimia telah menurunkan jumlah gugus -OH pada pengisi. Penurunan jumlah gugus - $\mathrm{OH}$ pada pengisi ini telah menyebabkan interaksi pengisi dengan matriks yang bersifat non polar menjadi lebih baik. Hal ini mengakibatkan menurunnya tegangan antar muka (interfacial tension) antara pengisi (STKS) dan matriks (UPR). Hasil yang diperoleh dengan menurunnya tegangan antar muka ini adalah meningkatnya ikatan antar muka dan pelekatan di antara pengisi dan matriks.

\section{Analisa Scanning Electron Microscopy (SEM)}

Karakterisasi morfologi permukaan patahan komposit ditunjukkan oleh analisis Scanning Electron Microscopy (SEM) dapat dilihat pada gambar 2, gambar 3 dan gambar 4.

Gambar 2 dapat dilihat morfologi patahan uji bentur dari (UPR) murni yang memiliki struktur kaku, dan rapuh. Gambar 3 morfologi patahan dari komposit rasio 80:10:10 (STKS tanpa modifikasi) menunjukkan bahwa pengisi telah menyatu dengan matriks (UPR), tetap masih terdapat fraksi kosong (void). Hal ini dikarenakan pengisi dengan matriks tidak menyatu dengan baik karena polaritasnya berbeda, sehingga ketika diberikan energi maka pengisi dengan mudah terlepas dari matriksnya (fiber bull out). Gambar 4 morfologi komposit rasio 80:10:10 (STKS dengan modifikasi) menunjukkan bahwa pengisi telah menyatu dengan baik dengan matriks (UPR). Hal ini dikarenakan 
dengan adanya modifikasi kimia pada bahan pengisi, maka polaritas pengisi dengan matriks hampir mendekati, sehingga ketika diberikan energi pada komposit, maka pengisi tidak mudah terlepas dari matriks.

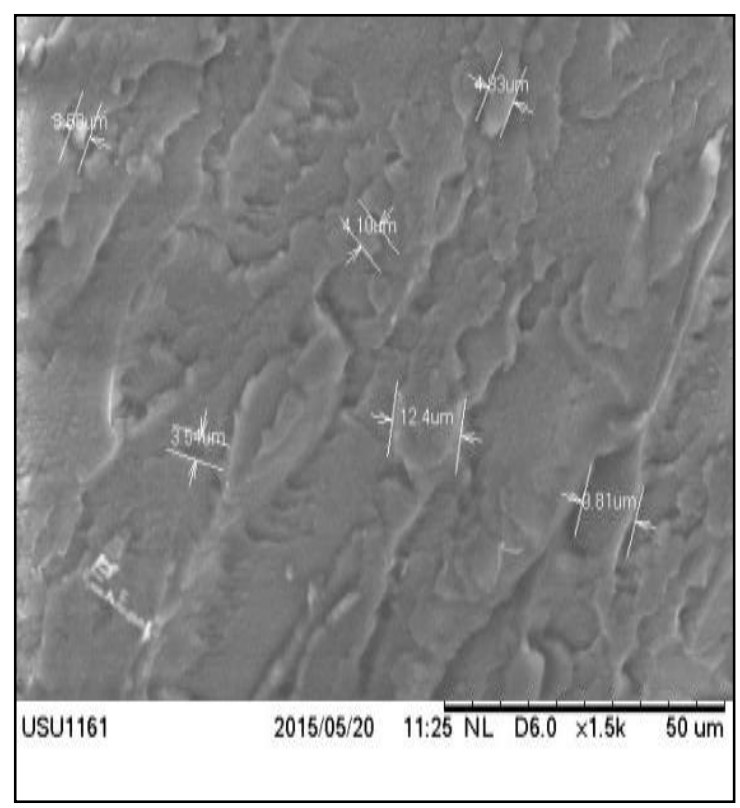

Gambar 2. Analisa morfologi (UPR) Murni Dengan Perbesaran $1500 \mathrm{x}$

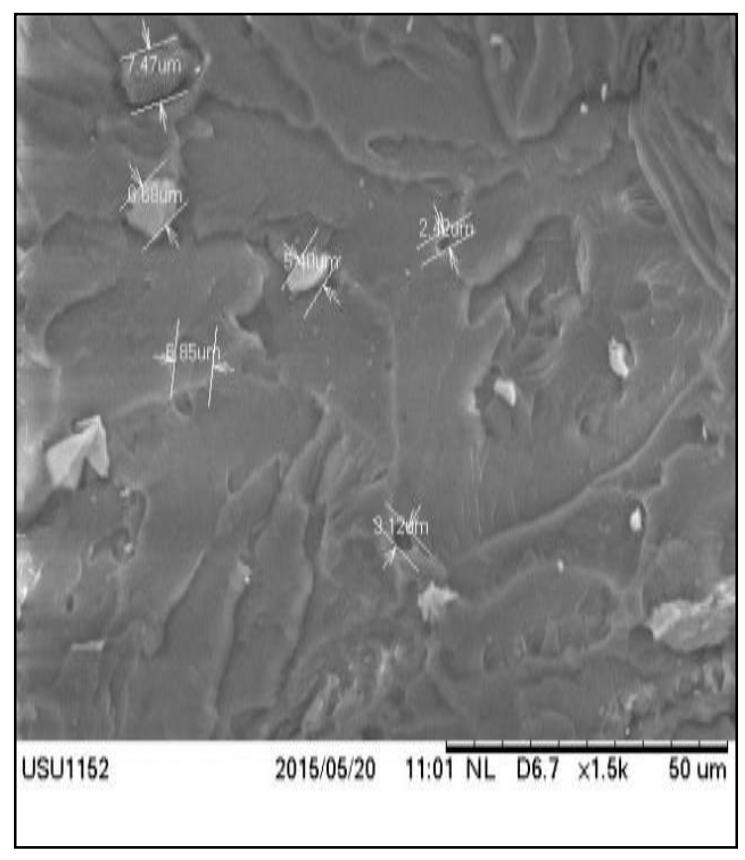

Gambar 3. Analisa morfologi komposit rasio 80:10:10 (STKS tanpa modifikasi) dengan perbesaran $1500 \mathrm{X}$

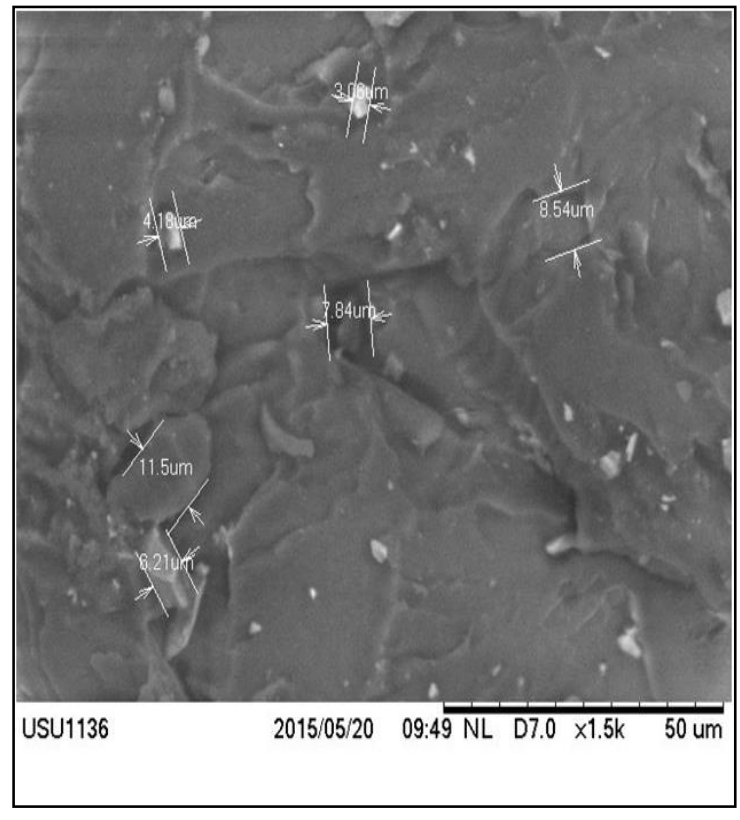

Gambar 4. Analisa morfologi komposit rasio 80:10:10 (STKS dengan modifikasi) dengan Perbesaran $1500 \mathrm{x}$

Pengaruh Komposisi Bahan Pengisi Dan Modifikasi Kimia Terhadap Penyerapan Air (Water Absorption) Komposit Hibrid Poliester Tidak Jenuh

Gambar 5 dan 6 menunjukkan pengaruh komposisi bahan pengisi dan waktu perendaman terhadap penyerapan air komposit masing-masing dengan dan tanpa modifikasi.

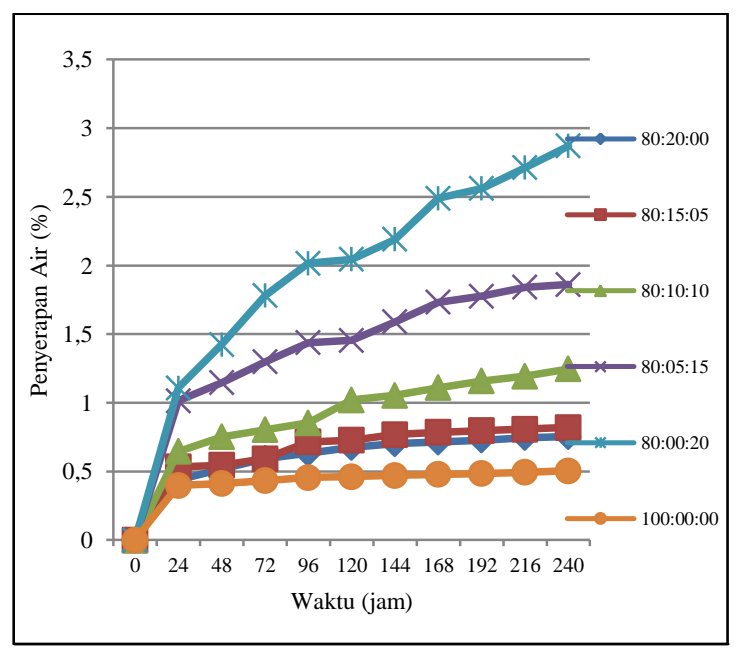

Gambar 5. Pengaruh komposisi bahan pengisi tanpa modifikasi terhadap persen penyerapan air komposit 


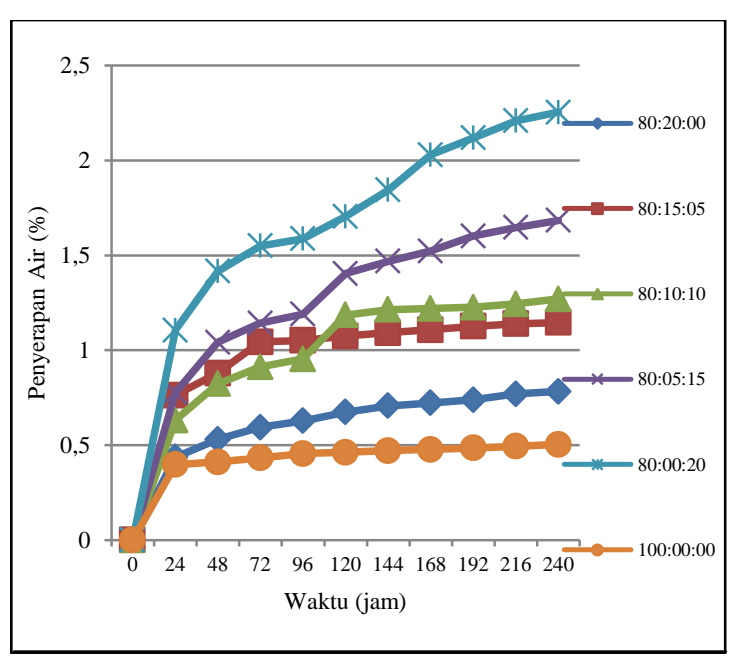

Gambar 6. Pengaruh komposisi bahan pengisi dengan modifikasi terhadap persen penyerapan air komposit

Gambar 5 dan 6 dapat dilihat bahwa penyerapan air bahan komposit akan semakin meningkat dengan penambahan kandungan bahan pengisi. Penyerapan air terbesar terjadi pada 24 jam pertama, kemudian diikuti oleh 48 dan 72 jam. Setelah itu, penyerapan air bahan komposit terlihat tidak begitu signifikan lagi. Dari gambar di atas juga dilihat bahwa \% penyerapan air pada 24 jam pertama yang tertinggi untuk pengisi serat tandan kosong sawit berada pada rasio 80:0:20, kemudian diikuti rasio 80:5:15, rasio 80:10:10, rasio 80:15:5 dan terakhir pada rasio 80:20:0. Hal ini disebabkan komposisi serat tandan kosong sawit yang paling banyak berada pada rasio 80:0:20 karena banyak mengandung serbuk tandan kosong sawit, dimana sifatnya dapat menyerap air.

Gambar 7 menunjukkan perbandingan persen penyerapan air antara UPR murni, komposit rasio 80:10:10 dan komposit rasio 80:0:20 dengan dan tanpa modifikasi kimia. Pada gambar 7 dapat dilihat bahwa penyerapan air pada komposit tanpa modifikasi lebih tinggi dari pada komposit dengan modifikasi. Hal ini disebabkan karena adanya modifikasi kimia dengan menggunakan asam asetat $50 \%$ pada pengisi STKS telah memutus gugusgugus $-\mathrm{OH}$ pada selulosa dalam STKS yang bersifat hidrofilik. Dengan berkurangnya jumlah gugus $-\mathrm{OH}$, maka STKS akan lebih bersifat hidrofobik. Dengan bersifat hidrofobik, maka komposit dengan modifikasi akan lebih sedikit menyerap air. Penyerapan air oleh suatu komposit disebabkan karena adanya ikatan hidrogen yang terbentuk antara gugus - $\mathrm{OH}$ pada serat alam dan air.

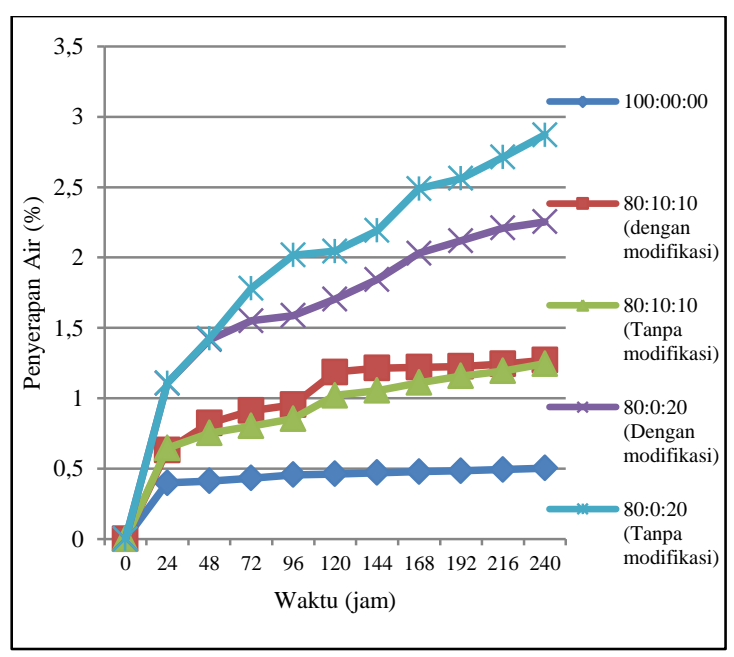

Gambar 7. Perbandingan persen penyerapan air antara UPR murni, komposit rasio 80:10:10 dan komposit rasio 80:0:20

\section{Kesimpulan}

1. Kekuatan bentur komposit STKS modifikasi lebih tinggi dari nilai kekuatan bentur komposit STKS tanpa modifikasi. Hal ini menunjukkan bahwa modifikasi kimia pada STKS dengan asam asetat $50 \% \quad(\mathrm{v} / \mathrm{v})$ telah berhasil meningkatkan ikatan antar muka dan pelekatan di antara pengisi dan matriks.

2. Dari hasil uji serapan air, menunjukan bahwa penyerapan air pada komposit tanpa modifikasi lebih tinggi dari pada komposit dengan modifikasi. Hal ini disebabkan karena modifikasi kimia dengan menggunakan asam asetat $50 \%(\mathrm{v} / \mathrm{v})$ pada pengisi STKS telah memutus gugus-gugus $-\mathrm{OH}$ pada selulosa dalam STKS yang bersifat hidrofilik.

\section{Daftar Pustaka}

[1] Bledzki, A.K., Gassan, J. The Influence of Fiber-Surface Treatment on The Mechanical Properties of Jute-Polypropylene Composites, Vol. 28, No. 12, (1997) p.1001-1005.

[2] Callister. Materials Science and Engineering an Introduction, Wiley \& Sons, Seventh Edition, University of Loa, New York, 1940 p. 224.

[3] Faisal, Tengku, Z. H. "Pengaruh Modifikasi Kimia Terhadap Sifat-Sifat Komposit Polietilena Densitas Rendah (LDPE) Terisi Tempurung Kelapa”, Tesis Magister, Sekolah Pascasarjana, USU, Medan, 2008.

[4] Gibson, F.R., Principle Of Composite Material Mechanics, International Edition, Mc.Graw Hill, New York, 1994, p.4-5.

[5] Lumintang, R.C.A., Soenoko, R., Wahyudi, S. Komposit Hibrid Polyester Berpenguat Serbuk Batang dan Serat Sabuk Kelapa,Tesis Pascasarjana, Teknik Mesin Universitas Brawijaya, 2011. 
[6] Marlina, L., Sriyanti, I., Iskandar, F., Pengaruh Komposisi Sekam Padi dan Nano Silika Terhadap Kuat Tekan Material Nanokomposit, Universitas Sriwijaya, Palembang, (2012), p.3.

[7] Nugroho, A.B ., Triono, L.B. Sintesis Partikel Silika Dengan Metode Spray Drying Dari Sol Silika, Tugas Akhir, ITS, Surabaya, 2006.

[8] Pangaribuan, S.H., Pemanfaatan Tandan Kosong Kelapa Sawit Dengan Perekat Polipropilena Hasil Daur Ulang Sebagai Bahan Papan Partikel, Tesis Magister, Program Pascasarjana, FMIPA USU, Medan, 2011.

[9] Porwanto, D.A., "Karakterisasi Komposit Berpenguat Serat Bambu dan Serat Gelas Sebagai Alternatif Bahan Baku Industri”, Tugas Akhir, Jurusan Teknik Fisika FTI ITS Surabaya, 2011.

[10]Rangkuti, Z., Pembuatan Dan Karakterisasi Papan Partikel Dari Campuran Resin Poliester Dan Serat Kulit Jagung, Tesis Magister, Program Pascasarjana FMIPA USU, Medan, 2011.

[11] Ray, D., Rout, J. “ Thermoset Biocomposites". Dalam Mohanty, A.K., Misra, M., Drzal, L.T., "Natural Fibers, Biopolymers, And Biocomposites", CRC Press : U.S.A, 2005, p.291 -345.

[12] Schwartz, M. M. Composite Materials Handbook, McGraw Hill Book Company, New York, 1984, p. 330-338. 